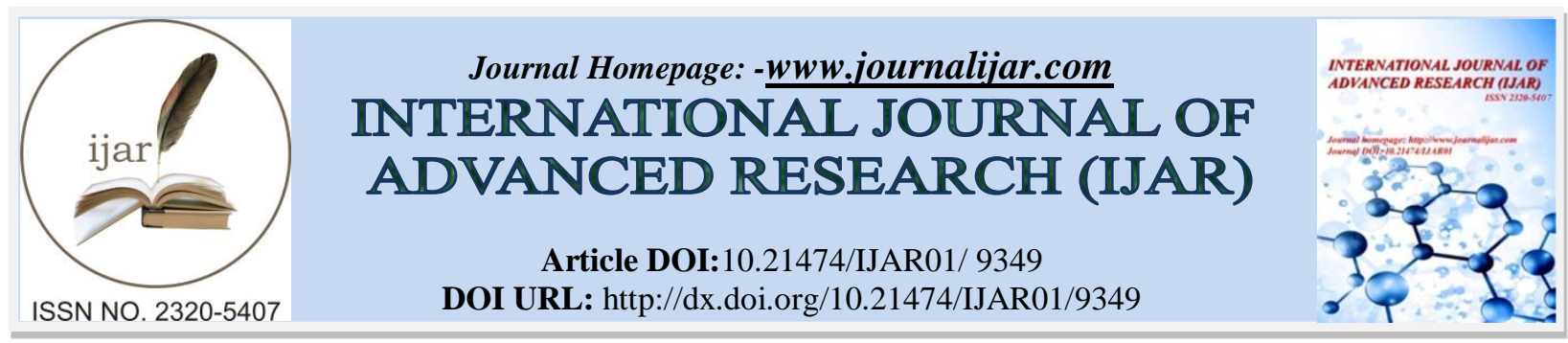

RESEARCH ARTICLE

\title{
PSYCHOLOGICAL BARRIERS TO LEARNING EFL LISTENING AND SPEAKING AT THE HSC LEVEL: A STUDY IN DHAKA DIVISION, BANGLADESH.
}

\author{
A.F.M. Moshiur Rahman ${ }^{1}$, Md. Khorshed Alam ${ }^{1}$ And Mohammad Mazibar Rahman ${ }^{2}$.
}

1. M.Phil Fellow, Department of English, Islamic University, Kushtia, Bangladesh.

2. Lecturer in English, Govt. Mujib College, Sakhipur, Tangail, Dhaka.

\section{Manuscript Info}

Manuscript History

Received: 05 May 2019

Final Accepted: 07 June 2019

Published: July 2019

Key words:-

EFL, HSC, Listening and Speaking,

Psychological Barriers, Anxiety.

\begin{abstract}
The study aimed at exploring the psychological factors affecting EFL listening and speaking at the HSC level. The researcher primarily reviewed extensive literature in the respective field and finally selected 12 HSC students from 3 colleges of Dhaka division, Bangladesh, as the participants of the study who were interviewed. Classroom observation technique was also applied for more data. The study unfolded issues like anxiety, lack of self-confidence, lack of motivation, fear of making mistakes, shyness and inhibition as the core psychological barriers to learning listening and speaking at the HSC level. It was also found that students needed more free and friendly teaching-learning environment, motivation and reward to reduce their psychological obstacles. It was observed that very less frequent teacher-student and student-student interactions occurred in the classrooms. Almost all the cases, students were passive regarding EFL listening and speaking practices. It was recommended that teachers' essential role in making fear-free classroom environment, positive feedback and proper motivation could break those psychological barriers to learning listening and speaking at the HSC level in Bangladesh.
\end{abstract}

Copy Right, IJAR, 2019,. All rights reserved.

\section{Introduction:-}

Listening and speaking are two major skills to be learnt at every level of education, especially at the Higher Secondary level in Bangladesh. The core purpose of Communicative Language Teaching in Bangladesh is to make the students skilled in listening, speaking, reading and writing skills but first two of them are not sufficiently emphasized yet because of the exclusion of these two skills in the HSC examination. Listening plays an important role in communication in people's daily lives. The centrality of listening in second and foreign language learning is well established today and an appropriate listening comprehension instruction is essential for target language competence (Morley, 2001), listening was one of the most neglected skills in second and foreign language classrooms especially until late 1960s. Both researchers and language teachers paid more attention to reading and grammar, and teaching listening was not accepted as a significant feature of language teaching (Richards \& Rodgers, 2001). Field (2008) states that "in the early days of English Language Teaching (ELT), listening chiefly served as a means of introducing new grammar through model dialogues" (p. 13). According to Huebner (1960), "Speaking is a skill used by someone in daily life communication by much repetition; it primarily a neuromuscular and not an intellectual process. It consists of competence in sending and receiving messages" (p. 5). In 
psycholinguistic, speaking is a productive language skill. According to Johnson (1998: 3), fluency refers to the absence of pauses and other indices of word-finding (or grammatical) difficulty.

Though listening and speaking are dealt with in the classrooms, some psychological factors including anxiety, inhibition, and fear of making mistakes, lack of motivation work as the barrier to learning those skills.

\section{Literature Review}

A number of studies have already been carried out in the respective field in different level of education at home and abroad to explore the psychological barriers to learning listening and speaking as the present study aims. According to Vandergrift (1999), metacognitive strategies lead to listening achievement when they deal with cognitive strategies. Vandergrift (1997) also undertaken an interview to examine the listening strategies of high school French students at different course levels. Students at all levels used metacognitive, cognitive, and socio-affective strategies. The results obtained from this study indicated that cognitive strategies were the largest percentage of strategies followed by metacognitive strategies which increased by proficiency level. Females were more interested in metacognitive strategies than males. Socio-affective strategies also increased by level course.

Burns and Joyce in Nunan (1999); Schwartz (2005); and Thornbury (2005) said that psychological factors such as anxiety or shyness, lack of confidence, lack of motivation, and fear of mistakes are the factors commonly that hinder students from speaking. Koichi Sato (2003) argued that students of English are not highly competent in speaking because of their fear of making mistakes. According to JIN Yan-hua (2007) students fail to join in the English discussion because of their vocabulary problems and fear of making mistakes resulting in their inability to speak English well. In addition, she says that students find speaking English a stressful activity especially if they have to perform something using English. The finding above confirms the results of this study as will be explained in part of the result finding

(Graham, 2006) explored that listening comprehension complexity can frequently cause irritation and anxiety among second or foreign language learners. Listening anxiety affects not only listening comprehension but also listening ability. Listeners"e anxiety will disperse their attention on the listening material, the sensitivity of auditory organ and reaction will be weakened, and such factors limit the amount of comprehensible input. Scarcella and Oxford (1992) unfolded that listening anxiety occurs when students feel they are faced with a task that is too difficult or unfamiliar to them. This anxiety is exacerbated if the 1isteners are under the false impression that they must understand every word they hear. (Horwitz1987) said that many learners believe that in order to be "good at a language they need perfect pronunciation, massive amounts of vocabulary, extensive grammar knowledge, overseas experience, and a natural aptitude for language before they even open their mouths.

According to Brown (2007), personality factors (i.e. gender, foreign language anxiety, shyness, willingness to communicate, etc.) are essential parts of the affectivity that raises our success in language learning. Nunan (1999) argued that student who lack of confidence about themselves and their English necessarily suffer from communication apprehension.

\section{Objective of the Study}

The focus of HSC English in Bangladesh is communication that would make the learners skilled enough in listening, speaking, reading and writing though the purpose is hindered regarding listening and speaking skills because of a number of psychological barriers. The present study titled "Psychological Barriers to Learning EFL Listening and Speaking at the HSC Level: A Study in Dhaka Division, Bangladesh." aims at examining the psychological barriers to learning listening and speaking at the HSC level and to recommend some suggestion to overcome the challenges.

\section{General Objective}

The general objective of the present study is to explore the learners' psychological barriers to learning listening and speaking at the HSC level in Bangladesh and provide research based solution.

\section{Specific Objectives}

1. to explore the psychological factors that affect learning EFL listening and speaking skills at the HSC level

2. to examine the impact of psychological factors on the achievement of the HSC students regarding listening and speaking skills 
3. to recommend specific solutions for improving the current scenario concerning the impact of learners psychological barriers to learning listening and speaking skills.

\title{
Significance of the Study
}

The present study is very significant for all the educational stakeholders to understand the causes that psychologically hinder the achievement of the learners regarding listening and speaking skills. It also will guide the teachers to encourage learners to interact more freely in the class and get involved in the tasks given; moreover, it aims to help learners to express their ideas and feel more comfortable inside the classroom. Recommendations of the study will help to create non-stressful classroom environment to improve students' self -confidence and enhance their self-esteems in different classroom activities. Finally, this study will elicit further studies as well.

\section{Methodology:-}

Based on the objective of the study, Mixed Method Approach has been applied to conduct the study. The researchers has dealt with secondary sources including the review of extensive literature and the experts' opinions regarding different psychological issues affecting learning listening and speaking skills and interviewed twelve students of HSC level from three colleges of Dhaka division. Three English classes from respective colleges were also observed to have practical data in the respective field of the study.

\section{Findings and Discussion}

This section is concerned with interpretation and discussion of the results of the study. The results are presented in three main sections. First section deals with the opinion of different experts concerned with the respective topic and the second section reveals the students' opinion through their interviews. Finally, the third section is about the practical results collected from the observation of classroom practices.

\section{Different Psychological Barriers to Learning EFL Listening and Speaking Skills}

This section deals with the findings based on the review of extensive literature of the respective arena.

\begin{abstract}
Anxiety
Anxiety is considered as the core psychological factor affecting achievement in every learning field, especially in learning listening and speaking skills. According to Arnold (2000, P. 59), language anxiety "ranks high among factors influencing language learning, regardless of whether the setting is informal (learning language on the streets) or formal (in the classroom)". According to Krashen(1981, P. 23), "The students who feels at ease in the classroom and likes the teacher may seek out more intake by volunteering and may not be more accepting of the teacher as a source of input." According to Hashemi (2011), language learners generally express tension, fear and anxiety when talking in another language. Language fear may be an outcome and in addition a reason for lacking charges of the target language. It might be experienced because of semantic troubles L2/ EFL students look in learning and utilizing the objective language. Inside social settings, language uneasiness might be experienced because of outward/extrinsic motivation. Saito \& Samimy (1996) assert that anxiety has a significant impact on language learning and achievement. Some studies conclude that high levels of anxiety usually have a negative effect on the language acquisition process (as cited in Wu, 2010, p. 174). Oxford (1999) indicated that anxiety damages language learners' achievement "indirectly through worry and self doubt and directly by reducing participation and creating overt avoidance of the language" (p.60). Kondo and Yong (2004) argued that second language anxiety could have a negative impact on learners' performance. It appears that anxiety debilitates second language learners' learning or performance in general.

Regarding listening anxiety, Oxford (1992) indicated that language learners are likely to become anxious when the listening tasks are too difficult or unfamiliar to them (as cited in Tallon, n.d. p. 7). Young (1992) said that listening comprehension is highly anxiety-provoking if the discourse is incomprehensible (as cited in Golchi, 2012, p. 115). And Oxford (1993) reported that anxiety frequently occurs when students feel that they cannot handle a second language listening activity. Speaking in front of other people using a foreign language seems to contribute the most to language classroom anxiety (MacIntyre, 1999; Horwitz et al., 1986; Young, 1991). Young (1990) explored that students consider speaking activities that require "on the spot" and "in front of everyone" performance to be the most anxiety provoking. Communication apprehension, social anxiety, and low self-esteem were considered three vital components of language anxiety. When making a mistake in a language classroom, students often worry that they are negatively evaluated, not only by their instructor, but also by their classmates (as cited in Liu, 2012, p. 124).
\end{abstract}




\section{Lack of Motivation}

Motivation consists of one's impulse, emotion and desire that makes him/her ready to move for a particular action. It can be intrinsic or extrinsic but it is an essential issue in learning listening and speaking skills. H. Brown (2001, P. 34) defined motivation as, "Motivation is the extent to which you make choices about goals to pursue and the effort you will devote to that pursuit." Gardner (1985) mentioned it as a combination of effort plus desire to achieve the goal of learning the language plus favorable attitude towards learning the language. Ramage (1990, p. 189)) pointed out that “identifying students' motivations for foreign language learning was a prerequisite to developing interventions that promote interest and continuation in foreign language study". Williams and Burden (1997) proposed, Motivation involved sustaining interest and investing time and energy into putting in the necessary effort to achieve certain goals. To sum up, motivation is the process by which goal-directed behavior is stimulated in language learning. It drives and directs behavior. Research shows that motivation directly and profoundly influences how often students use foreign language learning (FLL) strategies; how much input they receive in the language being learned; how high their general proficiency level becomes; and how long they persevere and maintain FLL skills after language study is over (Oxford, 1992).

\section{Self-esteem}

Self-esteem is a penetrating issue dealing with the attitude of approval or disapproval regarding a person's belief of being capable and successful in doing an activity. It is an important variable in second/foreign language learning. Gardner and Lambert (1972) included measures of self-esteem in their studies of success in language learning. Krashen (1982) also said that the students with high self-esteem will be in secure place and become successful in learning a language. On the other hand, self-esteem becomes one of big challenges for students to deal with their speaking performance mostly faced by adult students in university level (Jamila, 2014). H., Brown (2001, p. 23) mentioned that "I can do it" or self-esteem principle, i.e., a learner believes in his or her own ability to accomplish the task. "The eventual success that learners attain in a task is at least partially a factor of their belief that they indeed are fully capable of accomplishing the task."

\section{Fear of Making Mistake}

'Fear of making mistake' works as a serious barrier in speaking and in case of listening the fear of 'not being understood' hampers listening. Aftat, (2008) said that this fear is linked to the issue of correction and negative evaluation. This is also much influenced by the students' fear of being laughed at by other students or being criticized by the teacher. As a result, students commonly stop participating in the speaking activity (Hieu, 2011). The primary reason of fear of mistake is that students are afraid of looking foolish in front of other people and they are concerned about how other will see them (Kurtus, 2001). Chen (2010) mentioned that students feel afraid of the idea of making mistakes as they are worried that their friends will laugh at them and receive negative evaluations from their peers if they make mistake in speaking English.

\section{Shyness}

Shyness is a very common psychological phenomenon that usually hampers spontaneity of four language skills. This indicates that shyness could be a source of problem in students' learning activities in the classroom especially in the class of speaking. Therefore, paying attention on this aspect is also quite important in order to help the students do their best in their speaking performance in the classroom (Gebhard, 2000). In line with this, Baldwin (2011) further explains that speaking in front of people is one of the more common phobias that students encounter and feeling of shyness makes their mind go blank or that they will forget what to say.

\section{Findings from Student Interview}

While taking interviews of the students, all the students said that they felt anxious during listening and speaking practices because of many reasons including their poor background knowledge of English, very less practice of these two skills up to SSC level, and unfriendly environment of the classrooms. In response to another question, they opined that the feeling of making mistakes and negative judgment from teachers and peer hinder their spontaneity while involving in listening and speaking tasks.

They also believed that lack of self-confidence regarding EFL listening and speaking hinders their ability to face the difficulties that arise in listening and speaking. That's why they thought to be passive regarding respective activities for keeping themselves safe from being foolish and insulted by the teacher and peers. In response to a question concerning motivation, most of them said that they were not motivated enough to overcome all the psychological challenges by their teachers and institution. 


\section{Findings from Classroom Observation}

While observing the English classes, it was seen that most of the students were suffering from high level of anxiety regarding listening and speaking tasks. That's why they were unable to catch what teachers said and what was delivered from listening practice devices. It made them confused to interact with the teachers. Most of the students were afraid of making pronunciation and grammar related mistakes while speaking with the teachers and peers. It was also observed that when someone was doing mistakes, teacher was insulting him/her sometimes and other learners were laughing at him/her.

It was also explored that, for the less frequent listening and speaking practices, learners were feeling shy to deal with sudden situation. Lack of confidence was also observed among the learners regarding initiating EFL listening and speaking practices among the learners.

\section{Limitation of the study}

The study had a number of limitations as well. It was conducted only among the students. No teacher was included in the study. Again, the study included only three institutions of Dhaka division that might not provide generalized data as well. So, the study faces some limitations and shortcomings regarding unavailability of necessary data, information, literature and other relevant materials. Another issue was the use of limited instruments to collect data.

\section{Recommendations and Conclusion:-}

Based on the findings of the study, it is to recommend that learners' psychological barriers can be reduced through making a friendly and fearless classroom environment where every learner will get proper attention, motivation, positive feedback and reward. According to Young (1991), "recognizing learner manifestations of anxieties related to speaking, negative evaluation and foreign language learning-generated anxieties are important first steps in coping. Horwitz (1998) suggests teachers "discuss with their students reasonable commitments of successful language learning and the value of some language ability if it is less than fluent" (p.286).Language teachers need to be more sensitive to their students' fear and need. If a teacher becomes facilitator, then it will help the students and as well as the teachers. Young (1991) said that a teacher should provide the students comprehensible output and opportunities to communicate in the target language inauthentic situations with authentic materials. So, it can be said that instructors can play the vital role to reduce the psychological barriers of the learners to learning listening and speaking skill ensuring cordial and positive environment in their classrooms.

\section{References:-}

1. Aftat, Mokhtar, (2008), Motivation and Genuine learning. [Online] Available: http://www.englishteacher1.com/motivation.html (March 15, 2011)

2. Arnold, J. (2000). Seeing through listening comprehension exam anxiety. TESOL Quarterly, 34,777-786.

3. Baldwin, Caroline, (2011). How to Overcome Shyness During an Oral Presentation. [Online]Available:http://www.ehow.com/how_7852354_overcome-shyness-during-oral-presentation.html (February17, 2011)

4. Brown, H. (2001). Teaching by Principles: An Interactive Approach to Language Pedagogy.Beijing: Foreign Language Teaching and Research Press

5. Field, John. (2008). Listening in the Language Classroom. Cambridge University Press.

6. Gardner, R. (1985). Social Psychology and Second Language Learning: The Role of Attitude andMotivation. London: Edward Arnold Ltd

7. Gebhard, G.J. (2000). Teaching English as a Foreign or Second Language. USA: The Universityof MichiganPress.

8. Graham, C.R. (2006) Blended Learning Systems: Definition, Current Trends, and Future

9. Directions. In: Bonk, C.J. and Graham, C.R., Eds., Handbook of Blended Learning: Global Perspectives, Local Designs, Pfeiffer Publishing, San Francisco, 3-21.

10. Hashemi , Masoud . (2011) An investigation of the factors that cause anxiety among the English students of Islamic Azad University Of Hamadan in learning speaking skills and its influence on communication ability in the target language: Solutions and recommendations ,Unpublished Research Project Islamic Azad University, Toyserkan Branch, Iran.

11. Hieu, Trung, (2011), Students Lack Confidence To Use English. [Online]

12. Available:http://vietnamnews.vnagency.com.vn/TalkAround-town/212262/Students-lack-confidence-to-useEnglish.html(July15, 2011) 
13. Horwitz, E. K. (1987). Surveying student beliefs about language learning. Learner strategies in language learning, 119-129.

14. Huebner,T.(1960). Audio Visual Technique in Foreign Language. Newyork: CambridgeUniversity Press

15. Johnson (1998). Encyclopedia Dictionary of Applied Linguistics: A Handbook of LanguageTeaching. Blackwell Publishing Ctd.

16. Krashen, S. D. (1981). The input hypothesis: Issues and implications. London: Longman.

17. Kurtus, R, (2001), Overcome the Fear of Speaking to Group. [Online] Available:http://www.school-forchampions.com/speaking/fear.htm ( June 20, 2010)

18. Liu (2012). An Exploration of Foreign Language Anxiety and English Learning Motivation.Education Research International, Volume 2011, Article ID 493167.

19. MacIntyre, P. D. (1999). On the measurement of affective variables in second language learning.Language Leaming,

20. Morley, J. (2001). Aural comprehension instruction: Principles and practices. In M. Celce.

21. Nunan, D. (1999). Second Language Teaching \& Learning. USA. Heinle\&Heinle Publisher.

22. Oxford, R. (1992). Who are our students? A synthesis of foreign and second language researchon individual differences with implications for instructional practice. TESL Canada Journal 9, 30-49.

23. Ramage, K. (1990). Motivational factors and persistence in foreign language study. LanguageLearning 40, 189219.

24. Richards, J., \& Rodgers, T. (2001). Approaches and Methods in Language Teaching (p. 204).New York: Cambridge University Press.

25. Saito, Y., Samimy, K. K. (1996). Foreign language anxiety and language performance: A studyof learner anxiety in beginning, intermediate, and advanced-level college students of Japanese. Foreign Language Annals, 29, 239-251.

26. Scarcella, R. \& Oxford, R. (1992). The Tapestry of Language Learning: The Individual in the Communicative Classroom. Boston: Heinle \& Heinle.

27. Schwartz, R.L. (2005). Taking a Closer Look at Struggling ESOL Learners. [Online] Available:http://www.ncsall.net/?id=994 (March 3, 2011)

28. Thornbury, S. (2005). How to Teach Speaking. New York: Pearson Education Inc.

29. Vandergrift, L. (1997b). The Cinderella of Communication Strategies: Receptive Strategies in Interactive Listening. Modern Language Journal 81:494-505.

30. Vandergrift, L. (1999). Facilitating Second Language Listening Comprehension: Acquiring Successful Strategies. ELT Journal 53:168-76.

31. Vogely, A. (1999). Addressing listening comprehension anxiety. In D. J. Young (Eds.), Affect in foreign language and second language learning. A practical guide to creating a low-anxiety atmosphere (pp. 106-123). Boston: McGraw-Hill.

32. Williams, M. \& Robert B. (1997). Psychology for Language Teachers. Town of Cambridge: Cambridge University Press.

33. Yan Hua, Jin. (2007). Investigating the Difficulties in Speaking English for Academic Purposes; A Case Study ofan Overseas Chinese Student, Apr. 2007, Volume 4, No.4 (Serial No.40) China: Sino-US English Teaching.

34. Young, D. (Ed.) (1999). Affect in foreign language and second language learning:A practicalguide to creating a lou'-anxiety classroom atmosphere. Boston: McGraw-Hill.

35. Young, D. J. (1991). Creating a low-anxiety classroom environment: What does language anxiety research suggest? Modern Language Journal, 75, 426-439. 